\title{
Law Movement Facing Paradigm Post Truth in Social Media
}

\author{
Rini Fidiyani ${ }^{*}$, Erni Wulandari ${ }^{2}$ \\ ${ }^{1}$ Department of Private and Commercial Law Faculty of Law, Universitas Negeri Semarang, Semarang, Indonesia \\ ${ }^{2}$ Student of Doctoral Law Sebelas Maret University, Surakarta, Indonesia \\ *Corresponding author. Email: fidiyani.rini@gmail.com
}

\begin{abstract}
The era of disruption is almost experienced by every individual and society that is driven by information technology in meeting the needs of life. One of them is social media that surrounds every aspect of individual and community life. The purpose of this study is to explore and uncover legal movements in dealing with the post truth paradigm in social media, specifically targeting teachers in vocational high schools in the city of Purwokerto and the use of appropriate cultural approaches to contribute to the resolution of social media disputes. The research method used in the study of doctrinal and non-doctrinal law with anthropological approach to law. The results obtained by each dispute have a variety of weight and each dispute, especially social media. The study of legal anthropology views that the resolution of legal disputes is not singular and absolute opportunities are still open for various patterns of dispute resolution in social media as part of the legal form tangible and intangible. Settlement of disputes with social media can be pursued with the first alternative being to avoid each other, secondly; interact physically by reprimanding the perpetrator of the victim according to the culture of the third local community; request third party assistance, fourth; school leaders limit the movement of perpetrators who are proven to be troubling. The first conclusion is that the legal movement in social media is always active-dynamic and melts, especially interactions between the second netizens; cultural approach according to the character of the local community.
\end{abstract}

Keywords: law movement, social media, dispute resolution

\section{INTRODUCTION}

According to anthropological views, law functions in human life as a social control tool. Human life is dynamic, interesting and unique in meeting the needs of life. One of them is social media activities supported by the post truth era [1]. Since Barack Obama's campaign became president of the United States, then was adopted by Vladimir Putin and Donald Trump also used social media. The power of social media in political campaigning has a big influence on the success of the presidential election, especially to form opinions using buzzers.

Conditions for the formation of opinions via social media almost spread throughout all aspects of life both professions, locations and desired interests. Anthropological law in the processual approach has two aspects: the normative aspect and the cognitive aspect. Teachers at one of the vocational high schools in the city of Purwokerto, Banyumas regency, fulfil the task of producing students so that they can have vocational skills. Therefore, the teacher's profile and behaviour are required to set an example for students and the general public, including in social media. Several cases involving a small number of teachers from 38 respondents in 2019 out of 3 (three) teachers have repeatedly caused a stir in social media content that has been going on since 2017. The main factor is 3 (three) teachers who cause trouble on social media, especially Facebook due to disapproval of the leader's policy schools and foundations as well as conflicting interests with teachers who are socially adjacent to school leaders and foundations as a form of dissatisfaction. In the manuscript, we want to discuss the pattern of dispute resolution with a cultural approach as an acceleration of legal motion in social media.

\section{RESEARCH METHOD}

The research method is used in the study of doctrinal and non-doctrinal law with anthropological approach to law [2]. The qualitative approach method is used to observe actions and body language as well as certain words and symbols conveyed by the target being studied and the informants, through observation, interviews and documentation. The data source of this study was conducted primary, secondary and tertiary data sources in order to obtain valid data.

\section{THE LAW OF SOCIAL MEDIA}

The law of life and existence is no single and absolute because the law is interpreted by the community itself as the creator and supporter of culture. Society creates the law itself whether it is created, modified, manipulated, interpreted, and implemented by the citizens [3]. According to the anthropological view, the law is flowing and melting easily changes according to the needs of the times and the 
demands of the needs of human life. Anthropological view of this law is more grounded in the formation and enforcement of law in the midst of social life. This is contrary to the rule centered paradigm of seeing the law as a tool of social integration and a set of norms and habits of society that are used as guidelines for behaving rigidly and forcefully without compromise [4]. Legal anthropology in the study of cultural heritage holds the legal form is divided into two (2) according to the First Koenjtaraningrat; tangible can be touched physically and. Second; abstract can be felt in the form of legal behaviour patterns, legal culture mindset. Aspect of the tangible or intangible can be related to [5] a. Concepts about the object itself; b. Mining realized through the object; c. Fill in the message contained therein, especially if there is writing; $d$. Technology to make it or e. Patterns of behaviour related to its use. The two forms of law both tangible and intangible cycled to each other as important in the present demanding fast, precise and useful and fair as the final estuary.

\section{DISPUTE RESOLUTION PATTERNS SOCIAL MEDIA}

According to E. Le Roy [6] distinguish four basic attitudes of the disputing parties refer to the content of the order of the law or legal norms that live in society:

a. Orderly received; the parties resolve the dispute themselves;

b. Orderly negotiated; disputes become conflicts, there is a need for third party intervention; peace is restored in many ways, and legal norms serve as models, which are not coercive;

c. Forced order; the trial of this order signifies the transformation of the conflict into a court case which is solved by a judge must apply positive law;

d. The discipline that is refuted, the law applies the strongest or most capable; no external autonomy is able to mediate between the parties, each of whom uses methods deemed suitable to defeat his opponents, whereas the legal norms are refuted or voluntarily ignored.

Of the four rules above, it can apply to simple people to people who have high complexity, including those related to social media dispute resolution.

Types of social media activity findings in practice can be [7]

a. Distribution of getting news, information; this activity can be carried out by parties who need data with various interests.

b. Distribution of making news and information; this activity can be carried out by interested parties to influence public opinion so that it can convince the news content in the form of videos, pictures, words or comments and so on

c. Distribution of news and information spread; helping newsmakers or information either with permission from newsmakers or deliberately inviting responses;

d. Blocking other people's accounts from being connected again due to various factors, such as accounts that endanger citizens of pornography, porno-action, terrorism, paedophilia, and forbidden ideology.
The theory of dispute resolution in the study of legal anthropology begins with a process on how to handle disputes which varies greatly from the opinions of Nader and Todd [8]

a. monadic, the party who is harmed or treated unfairly can culminate because of a confrontation, but he avoids contact with the second party, or the second party does not react to the challenges of the first party;

b. In addition, each party to the dispute has entered the stage of conflict, but both are aware of the existence of a disagreement between themselves;

c. triadic, can occur if the debate has been entered into the public sector which is done deliberately and actively with the intention that there is something action about the desired demands.

The condition of the three ways of handling disputes above is easily influenced by several factors

a. first factor; character and stratification of the disputing parties;

b. second factor; dispute weighting,

c. third factor; location of dispute and

d. fourth factor; object of dispute

The three ways of handling disputes can disappear and reform and fluctuate, because they are influenced by the factors above.

The pattern of dispute resolution with cultural approaches adopted in accordance with the local wisdom of an egalitarian, open and honest district community in speaking there are several ways to be taken, including:

Settlement of disputes with social media can be pursued with the first alternatives to avoid each other, secondly; interact physically by reprimanding the perpetrator of the victim according to the culture of the third local community; request third party assistance, fourth; school leaders limit the movement of perpetrators who are proven to be troubling.

\section{CONCLUSION}

The first conclusion is that the legal movement in social media is always active-dynamic and melts, especially interactions between the second netizens; cultural approach according to the character of the local community.

\section{ACKNOWLEDGMENT}

Thank you is conveyed to the Rector of Semarang State University, Chair of the Semarang State University Research and Community Service Institute, Dean of the Faculty of Law, Semarang State University; Research informant; Research Respondents. All of the above parties have provided support and assistance for the smooth-based research in the UNNES DIPA fundamental scheme in 2019. 
http://www.huma.or.id/document1/03 gagasan dalam hukum/UpDate19Agst04/AntropologiHukumPerkembanganTemaKajianINyoman.pdf

[4] Results of observations and interviews from informants during July - Agustu 2019 in Semarang State University

[5] Edi Sedyawati, 2012, Budaya Indonesia Kajian Arkeologi, Seni dan Sejarah, hlm.161

[6] John Griffiths, 1986, What is Legal Pluralism, artikel dalam Journal of Legal Pluralism and Unoficial Law, No.24, The Foundation of Journal of Legal Pluralism;

[7] Norbert Rouland, 1992, Antropologi Hukum, Yogyakarta: Universitas.Atmajaya, pg.64-65

[8] TO Ihromi, Ed, 2001, Antropologi Hukum, Sebuah Bunga rampai, Jakarta, Yayasan Obor Indonesia, pg. 225 